\title{
Music teaching in regular class and extracurricular music activities in Croatia: State and perspectives
}

\author{
SABINA VIDULIN*
}

Department of Music Pedagogy, University of Juraj Dobrila of Pula, Academy of Music in Pula, Pula, Croatia

\section{THEMATIC ARTICLE}

Published online: July 20, 2020

(c) 2020 The Author(s)

\section{ABSTRACT}

In the last 30 years Croatia has been involved in an intensive period of educational reforms. Music teaching, as a compulsory subject, underwent some positive and negative changes. The so-called open model and contents remake bring the possibility for teachers to be more creative and for students to be involved to a greater extent, but unfortunately, music lessons come to just $1 \mathrm{~h}$ per week. As a part of the Croatian school system, the extracurricular music activities are implemented in the school curriculum which affects the acquisition of new knowledge developing students' musical skills. This paper aims to present the today's situation of attending music classes in regular and extracurricular lessons in Croatia. Moreover, it discusses the international research project Schools@Concerts: Tuning up for the Music Experience which influences the idea how to carry out another kind of extracurricular musical activity which suits the worldwide environment. The intention is to familiarize students with (classical) music during the work in the extracurricular activity and by visiting to a concert. The author presents her own idea how to realize the extracurricular music activity Listening to Music with Concert Experience carried out by a cognitive emotional approach to listening to music which contributes to the students' music appreciation and preservation, transfer, renewal and dissemination of cultural heritage.

\section{KEYWORDS}

concert experience, extracurricular class, music activities, music appreciation, music education, project

\footnotetext{
*Corresponding author. E-mail: svidulin@unipu.hr
} 


\section{MUSIC TEACHING IN CROATIAN COMPULSORY SCHOOLS}

In the last thirty years Croatia has been involved in an intensive period of educational reforms. "Numerous proposals, documents, plans, programs, projects and strategies published from 1990 onwards were aimed at changing the educational structure and improving the efficiency and effectiveness of school" (Vidulin, 2016a, p. 346). Over the years, educational goals, tasks and teaching contents were changed and the modernization of the school system was aimed at.

Since music teaching in compulsory school is one of the subjects and an integral part of the curriculum, in the last decades, it has experienced some changes. With two hours per week from the fifth to the eighth grades, it dropped to $1 \mathrm{~h}$ per week, which was a negative consequence of the reforms. All interventions done were smaller and almost insignificant. Nothing has actually been done with regard to modernizing the content of music teaching and changing its concept, which has been based on singing since the Second World War.

We have detected a new period for music teaching since 2005, which started with the introduction of the reform titled Hrvatski nacionalni obrazovni standard [Croatian National Educational Standard], in the period when the Nastavni plan i program [Teaching plan and program] (2006) for all subjects at the compulsory school level was adopted and the reform continued with the establishment of the Nacionalni okvirni kurikulum za predškolski odgoj $i$ obrazovanje te opće obvezno i srednjoškolsko obrazovanje [National Curriculum Framework for pre-school education and general compulsory and secondary education] (2011). Since 2006, teaching music in the compulsory school has been organized in accordance with the so-called open model, where the areas of listening to music with the elaboration of music literature became the only compulsory activity, while singing, playing, music literacy, and creativity gained a secondary role. The second group of activities was selected by the teacher in accordance with the student's affinities, interests, dispositions and abilities. Also, there was a reduction in content, so the material for teaching music at compulsory school was somewhat simplified and reduced.

Today, Croatia is facing a new reform called Curriculum Reform "School for Life." The curriculum approach seeks to ensure the quality of education, and the outcomes are revised according to the needs of the individual and society. After a one-year experimental application of the curriculum approach, a new document of the Predmetni kurikulum za nastavu glazbe u osnovnoj i srednjoj školi [Subject Curriculum of Music for Primary Compulsory and Secondary Education] (2019) was adopted. By inheriting the quality and usefulness of the previous curricula, and taking into account the contribution of the Croatian National Education Standard, the Subject Curriculum for Music Culture and Musical Art focuses on students and schools, and is important as such for the community and society (Šimunović, 2019).

The Decision $^{1}$ on bringing the Kurikulum za nastavni predmet Glazbene kulture za osnovne škole i Glazbene umjetnosti za Gimnazije u Republici Hrvatskoj [Curriculum for Music Culture in the Compulsory School and Music Art in Gymnasiums in the Republic of Croatia], states that music teaching "promotes and improves student esthetic development, stimulates student creativity, develops students' musical abilities and interests, develops student awareness of the conservation of historical and cultural heritage and enables them to live in a multicultural

${ }^{1}$ Odluka NN, 7/2019 (Official Gazette no. 7/2019) (22 January 2019). 
world" (2019, pp. 2-3). The educational objectives of Teaching Music Culture/Musical Arts are: "to enable the socio-emotional development of all students, including gifted students and students with disabilities; to encourage the development of musical abilities of all students in line with the individual's abilities; to encourage students to actively engage in music and participate in the community's cultural life; to familiarize students with musical art through quality and representative performances of music of different origin and different styles and types; to encourage the development of musical taste and critical thinking; to foster understanding of the interdisciplinary characteristics and possibilities of music; to raise awareness of the values of regional, national and European cultural heritage in the context of world culture; to develop cultural understanding and intercultural competence by building relationships towards their own and an open approach to other musical cultures" (ibid., p. 4).

The structure of the Subject Curriculum is divided into Domain A, which includes Listening to Music, Domain B, Music Expression, and Domain C, Music in Context. Domain A outcome is to learn music through audio and video inserts so that students learn about music of different types, styles, and genres, acquire knowledge of music-expressing components, levels of music composition, and experience, understand, and learn how to evaluate music. Within Domain B, students perform musical activities by singing and playing, including music games, music creativity, music movement. Domain C comprises domains A and B, on the basis of which the student discovers the values of rich regional, national and global musical and cultural heritage, observes the development, role and influence of musical art on society and connects music with other arts.

Depending on the educational cycle, students' musical knowledge and skills are complemented by listening experiences and active musicianship, so at the end of compulsory school students are able to experience, recognize, understand and evaluate music, its components (tempo, dynamics, mood, character, melody, rhythm), formal structure (from motive to threepart song, theme with variation, rondo), form cycles (string quartet, sonata, suite, concert, symphony), performers and performing corps (instruments, voices; vocal, instrumental and vocal-instrumental music), music-stylistic periods (from the beginnings of civilization to the present day). The importance and relevance of individual domains is changed with respect to the educational cycle, but also by the teacher's decision, and in the interest of students and the specifics of the School Curriculum (Šimunović, 2019).

It is evident that the so-called open model with an emphasis on listening to and learning music continues to be practiced, and teachers can now choose the domains in relation to each particular cycle, taking into account the interest of students and coordinating the goal, tasks and outcomes with the aims of the school curriculum.

Although the subject curriculum also addresses extracurricular activities, this is still to a lesser extent mostly declarative. Since extracurricular activities are an excellent way of dealing with a particular area of students' free time, we want to emphasize their value and importance.

\section{EXTRACURRICULAR MUSIC ACTIVITIES IN THE CROATIAN SCHOOL SYSTEM}

In the Croatian educational system, students can spend their free time in school, which is organized and run by experts - school teachers. According to the results of the research about 
organized leisure time conducted by Croatian and foreign scientists (Broh, 2002; Delle Fave \& Bassi, 2000; Gilman, Meyers, \& Perez, 2004; Ilišin \& Radin, 2002; Marsh \& Kleitman, 2003; McHale, Crouter, \& Tucker, 2001; Mlinarević \& Brust Nemet, 2012; Pejić Papak \& Vidulin, 2016; Prlić \& Ilić, 2000; Vidulin, 2019; Vidulin \& Pejić Papak, 2018), it is important for the integral development of the child because it promotes their intellectual, emotional and social development. In addition to working together in a peer group, students acquire knowledge, develop their skills, encourage their creativity and get the possibility to be innovative. Thus, by organizing students' free time through various extracurricular activities, the school, which is primarily an educational center, becomes a place where students start distinguishing themselves with regard to their interest, acquire competences and advance towards their capabilities.

Participating in extracurricular activities through research, projects, performances, students come out of school and have the opportunity to participate in the life of their community, integrate themselves and be recognized in the social environment in which they live.

According to the Croatian Teaching Plan and Program (2006), there are eight areas of interest in extracurricular activities: linguistic-artistic area; natural-mathematical area; sport and health-recreation area; nurturing national and cultural heritage; conservation of nature and environment and healthy lifestyle; socio-humanistic projects and workshops; student cooperative area; technical creativity.

Extracurricular activities are planned with a school curriculum that determines the types of extracurricular activities, the number of groups and the time in which, on a weekly and annual basis, a certain extracurricular activity takes place. Each school develops its own system of extracurricular activities that depends on the teachers and their affinities, knowledge and skills, and especially in relation to the interests of students. Extracurricular programs are implemented throughout the school year, with permanent groups. During the activities, the student's active participation, team work, immediate experience, research, critical thinking and presentation, group presentation, transfer of knowledge to new situations and application of knowledge are encouraged. Also, students have the opportunity to improve their competences beyond regular teaching and show their results at exhibitions, performances and competitions.

One of the most frequently selected area is extracurricular music activities. The research results of Vidulin-Orbanić (2007) show that more than $40 \%$ of students are involved in extracurricular music activities in Croatia. Flammer \& Schaffner (2003) point out that music activities are significantly represented in children's free time. Beginning with various extracurricular music activities, students start to discover, experience and explore music in a more open and flexible way, develop and enhance their skills, acquire new knowledge and actively participate in the community's musical life.

In the Subject Curriculum (2019, p. 3), the following is stated: "An important part of the learning and teaching process is related to elective and facultative teaching, and extracurricular and out-of-school activities within which students expand their acquired knowledge, skills and attitudes while simultaneously systematically developing their interests and achieving a high level of artistic growth and development." These activities are connected to regular music teaching, and that can be seen in the curriculum which mentions that through the B domain of the subject curriculum it will be possible to realize various extracurricular activities such as choirs, instrumental ensembles, orchestras, dance groups, folklore ensembles, compositions, individual performances and the like. The subject curriculum notes that extending the learning and teaching of music, along with extracurricular activities, can be done through elective and 
facultative subjects and programs, projects, as well as through out-of-school activities. 2 "The above-mentioned forms of work enable the quality development of each student. They represent an effective way of preventing socially unacceptable behavior, so they are recommended in all cycles and years of learning" (Subject Curriculum, 2019, p. 72).

The advantages of student participation in extracurricular music activities are numerous: with music progress, they develop their personality, individuality, improve critical thinking, and their creative potentials and originality come to the fore. Collaboration is expressed; consequently, different opinions, states and feelings are manifested, while communication, decisionmaking, building trust, and self-evaluation is done in relation to others, etc. With progress in the field of music, they become accomplished individuals and members of the community; their development is promoted, they become expert and competent individuals, and their human and social personalities are developed and they therefore become more independent and responsible persons.

It is important to emphasize that these activities are voluntary, flexible in planning and implementation, open to all children, regardless of their abilities. Contents and strategies are planned by teachers and students. They are tailored to students' needs, desires and preferences, enabling grouping of students of different ages, and including: "music workshops, playrooms and listening rooms; different ensembles (chamber ensembles, choirs and orchestras); artistic projects in which other arts (including musicals, musical-dramatic recitals) have been implemented with music; interdisciplinary projects in which music is linked to other subjects/areas/ interpersonal topics; out-of-school teaching that includes visits to musical-cultural institutions and musical-educational excursions" (Subject Curriculum, 2019, p. 73). After students choose the type of activity they want to participate in, a group of students of the same interest that works on a common goal is formed. During their activities, they actively participate, work as a team, have immediate experience, think critically and present their ideas, make group presentations, which all together contributes to their common success.

The existing extracurricular music activities conducted in Croatian compulsory schools, according to available online sources, are the following: choir, vocal groups, playing, performing in ensembles, folklore, dance, composition, music workshops, music projects, music listeners groups. The most common activity is the choir. In the research carried out by Vidulin (2016b), the results show that the largest number of teachers lead the school choirs (97.4\%), indicating the primary and most commonly performed extracurricular activity in Croatian schools - the choir. According to the results of the same survey, there are only half as many teachers who decide to perform the activities of solo playing and playing in the ensemble. Much lower is the number of those who lead vocal groups, music projects, then musical creation activities, music workshops and dance, while the least conducted are activities of composing, music listening and music literacy.

The activities offer is one of the primary criteria in the structuring and organization of extracurricular activities work, and therefore the identification of the students' interests for a

\footnotetext{
${ }^{2}$ The difference between extracurricular and out-of-school activities is that the first ones are spent at school with experts from a particular area and are not charged, while out-of-school activities are carried out in various organizations and monthly membership fees are charged. It is not required for these activities to be conducted by experts, but they can also be amateurs - enthusiasts.
} 
particular area should be carefully explored and their age, interests and abilities should be considered when planning and organizing them.

Although extracurricular music activities are frequent in Croatia, more attention needs to be devoted to the designation and offer of new programs and contents. Due to the reason that nothing is prescribed and rigidly defined, numerous possibilities have been left to include new topics and content, but also the methods of work. It is desirable that the program content be the expression of students' desires, but adapted to the working conditions and specificities of a particular school. If the content offered to students is of interest to them, with innovative and contemporary ways of working, it is highly likely that more students will be involved in the activity.

Nevertheless, regardless of the quality of certain activities, results and their contribution to the overall development of students, the extracurricular (musical) activities are neglected by state bodies and schools; no greater attention was paid to them in pedagogic acts; there is no systematic plan for their dissemination and modification although it is well-known that they affect the students' well-being. One hour per week class is by no means sufficient for the expected results and often teachers-enthusiasts work with students from two to $5 \mathrm{~h}$ a week to achieve high-quality results. The lack of adequate space, teaching resources and aids also represent a challenge. In order to encourage and retain the teachers' enthusiasm it is important to provide support from schools, extracurricular organizations, the Education and Teacher Training Agency, the Ministry of Science and Education, as well as more frequent and targeted professional training and presentation of results.

\section{NEW POSSIBILITIES AND IDEAS FOR DEVELOPING EXTRACURRICULAR MUSIC ACTIVITIES}

Although there are plans, programs and results of new models and approaches to extracurricular music activities through composing, musicals, etc. (Vidulin-Orbanić, 2013), teachers have an open possibility of conceptualizing new and different activities. These activities can be exclusively music-oriented, but also interdisciplinary. We will feature an activity that can be organized year round, with an emphasis on listening to music by experiencing concerts.

The idea for planning the new extracurricular music activity was created on the basis of an international research project designed and conducted by colleagues from eight European countries (Austria, Croatia, Ireland, Great Britain, Serbia, Poland, Macedonia, Germany) under the title Schools@Concerts: Tuning up for the Music Experience. “The comparative research project tends to find, examine, analyze and compare the youth getting in touch with classical music in different countries that reveals cultural, national and individual varieties. Schools cooperate with concert hosts to give students the possibility to attend classical concerts. The research investigates the following main topics: goals, expectations and roles of the persons involved (students, music teacher, concert host); preparation process and follow up activities within the cooperation project; students' experiences in connection to the concert attendance" (Bernhofer, Vidulin, \& Beqiri-Vula, 2020). 


\section{Project Schools@Concerts in Croatia: basic information from the research}

The Croatian project took place on April 10th 2018 in Zagreb. In the Music Week for the Youth (Tjedan glazbe za mlade) at the Concert Hall Vatroslav Lisinski, the Zagreb Philharmonic Orchestra held the concert titled: "Impressionism in Music".

The three parties participating in the research in Croatia were: students and their music teacher from the compulsory school from Slavonski Brod and the host Croatian Music Youth (Hrvatska glazbena mladež). The research encompassed 36 students, 12 to 15 years-old.

The data was collected by interviews and questionnaires as well as by open-ended questions. There were two steps: collection of data before the concert and after the concert. The results ${ }^{3}$ show that students expect from the concert to be interesting, relaxing, pleasant, to have fun, but also to learn something new and hear the musical instruments live. After attending the concert, according to the top five statements from the questionnaire scale, students put music first to a great extent. In a wider context the results show that it was pleasant for all the 36 interviewed students. The students said that they increased their interest in listening to classical music.

From this experience, they learned that: "Classical music is valuable and you need to be patient to learn it.", "Each instrument is unique in its own way", "It is not true what my father said that classical music is boring", "Music is beautiful when listening to it live", "There are many kinds of music and we can better understand music with dancing", "A man must listen to and try to find what he/she likes", "We should never "judge the book by the cover" and "Much time is needed to prepare the concert, musicians invested a lot of time in it and that should be appreciated."

Students commented that listening to live music at a concert is much better than listening to recorded music in class; they liked listening to the entire piece as well as seeing the musicians play. Those students would like to go to a concert with classical music again (35 of 36 in total), and all of them will suggest to other students to attend classical music concerts.

Regarding the teacher, she highlighted that by going to the concert students developed a habit of visiting classical concerts. The goals were: to experience a classical concert and live music; to introduce students to valuable art works; to experience a multimedia concert of classical music; to explore their experience after the concert.

Regarding the aims, she expected that by actively listening to music students would encounter and better understand the art works, appreciate and show interest in classical music, more so than before visiting the concert.

Participating in the concert, students had the opportunity to experience and listen to classical music performed by a live orchestra. They learned that live music performances are more realistic than performances on $\mathrm{CD}$ or YouTube and realized that concerts are something nice to visit. These statements are in total accordance with the above-mentioned from the students' point of view. Moreover, they were expected to change their opinions regarding classical music and to show a positive attitude toward classical music, and this really happened.

The unexpected outcomes of this project were the completely different experiences of students - their different reactions and feelings. The insight into their feelings expressed something

\footnotetext{
${ }^{3}$ The results obtained from students are described in the paper European comparative research project Schools@Concerts: Experiences from Croatia and Macedonia (Bernhofer, Vidulin, Beqiri-Vula) and here we pointed just a few of them to have an idea.
} 
that they had no opportunity of seeing and listening to in class, and now they have experienced it. The main result is their full satisfaction and their wish to go to a classical music concert again. They have learned that this is a valuable experience and that a classical concert should definitely be visited.

It can be concluded that both the teacher and the students are satisfied with the concert and have the desire to repeat this experience. The same applies to colleagues and friends who, listening about the concert and the positive experience encountered, wanted to go to one such event.

Working on this project as a researcher, the idea of how to conceive an extracurricular music activity emerged, thus offering a new possibility of approaching extracurricular music activities.

\section{LISTENING TO MUSIC WITH THE CONCERT ADD-ON AS AN EXTRACURRICULAR MUSICAL ACTIVITY}

Extracurricular music activity Listening to music by experiencing concert is based on listening to and learning about music literature and is conducted in the classroom and beyond the classroom. In 70 school hours ${ }^{4}$ (twice a week), students first listen to, experience, analyze, and evaluate the musical works the teacher chooses. It is recommended that the works should not be listed in the curriculum because these works are taught during regular music teaching. With audio, video examples are also important, and performance quality is a prerequisite, as it affects the experience, as well as a better understanding of music. The repertoire should be carefully designed and representative for students to be interested in and motivated for further listening. The presented works need to have an artistic base and musical recognition.

Listening to and learning about music in an extracurricular music activity is carried out by a cognitive-emotional approach. In the cognitive-emotional approach (Vidulin \& Radica, 2017), along with the recognition and distinction of the structural musical compositions of the work, students tend to accept artistic music as their own, and the original music experience is of utmost importance. Approach to music listening should be directed primarily to students, their experience, understanding and acceptance of music. "The first step in that direction is to select high quality, valuable musical examples that will appeal to children and encourage them to deepen their understanding and acceptance of artistic music, leading them to the perception of the nice in the art of music but also around them. It is important that students listen to music, feel, comment and express their impressions and judge and evaluate it" (Vidulin \& Radica, 2017, p. 62).

The aim of listening and learning music in the extracurricular music activity is to shape the student's cultural-artistic worldview and contribute to their esthetic education. The purpose of listening to music is, in effect, affecting the student's perception, understanding and acceptance of music.

Listening to and understanding music is accompanied by singing and playing famous parts, dancing and choreography, dramatization and other musical and non-musical elements that would contribute to careful listening and music appreciation. The work should also be set up in

${ }^{4}$ It is also achievable in 35 hours per week, but with less contents. 
a particular context (dedication, time of creation, composer's life and work, social circumstances, and so on), which would further attract students. Tasks set should be targeted so that the work is easier to follow and understand.

Before listening to music it is necessary to set up simple tasks: from defining the composer and work title, tempo, dynamics, character, performers, musical forms, types to finding melodic and rhythmic specifics of each piece. It is appropriate to listen to it several times, with different tasks because listening to the work a few times, and considering it from various aspects, will result in better music understanding (Vidulin \& Martinović, 2015).

Tasks assigned to students should be simple, from determining the composition's title and the composer's name, tempo, dynamics, mood and character, performers (instruments, voices, music groups), musical forms, types, melodic and rhythmic specifics, all with regard to their age and former knowledge.

The first phase of the work involves the work of teachers and the offer of works they consider relevant to the age and culture of the students they work with. It involves a great engagement of teachers in the work preparation and didactical elaboration. Merely their method of preparing the work of this elaboration becomes a model according to which the students, in the second phase, will explore and prepare themselves the musical works that would be presented to other members of the group. Choosing musical works should not be limited to art works but it could be one of the conditions, since it would be desirable for students to get acquainted with art music during this activity. The first phase lasts from September to December, encompassing at least 15 different musical works ${ }^{5}$ and combines it with going to a concert. ${ }^{6}$

The second phase implies that the students themselves choose the work they will show and listen to with their colleagues, and which they will need to prepare: explore, prepare a lecture, a handout with tasks and activities they want to show and work on in $1 \mathrm{~h}$. One lesson would be enough to present a piece of work. This phase lasts for the second school term and is combined with going to a concert. Going to a concert should be organized at least twice in one school year.

The intermediate phase - attending a concert, or going to the concert, must be thoroughly prepared. At the beginning of the school year, and after defining a group of students participating in the activity, the teacher should check out which concerts are held in the city and its surroundings and predict which concerts the students are going to attend. After obtaining a permission from the school principal, a parent meeting is organized to obtain the parents' permission to attend concert events, as well as their financial support to pay tickets for concerts and possible transportation to the venue of the concert. It is also possible that the school finds funding sources for this activity so that students can attend the concert free of charge.

Before going to the concert, at school, during the extracurricular activity, the work that will be listened to live is presented so that the students get fully prepared for the music awaiting them. Moreover, with various research tasks the students are motivated to study the work from all perspectives. Students create presentations, posters, write seminars, and do many other

\footnotetext{
${ }^{5}$ It is desirable to process at least ten musical pieces of artistic provenience, as students will presumably choose another type of music that is closer to their preferences. Nevertheless, it would be interesting to set before them the task to independently process a work of art according to their wishes, even if those were familiar and liked during regular music classes.

${ }^{6}$ The genre is chosen by the teacher in co-operation with the students. It is desirable to plan to go to a concert of art music in a prestigious music building (we mean concert halls, theaters).
} 
activities. The live experience, namely going to the concert, is what follows. After the concert, an educational lesson is organized during which students express their opinions and attitudes, emphasizing the musical and non-musical contexts (hall, atmosphere, audience, etc.). The conversation is based on the following questions: Describe your experience of the concert.; What did you learn at school regarding the music work and concert in general?; What do you think of the concert? (What do you remember most about the concert: music, atmosphere, audience)?; Was it a pleasant or unpleasant experience for you and why?; What was the most interesting thing in the live performance?; What did you learn from this experience?; What are the differences between listening to live music at the concert and in the classroom?; Would you like to go to a concert of art music again?

After the concert, it is useful for the students to create a poster, a review, a report and a drawing to present the musical work, and regarding their experience, they can talk about it to other students as well, during regular music teaching.

The Music Listening Log should be kept during the school year, in the form of a notebook describing the whole experience, containing analysis, synthesis and evaluation, or some other form of e-diary can be realized in collaboration with the group of school computer scientists.

\section{CONCLUSION}

Music in Croatian schools, although with only $1 \mathrm{~h}$ per week, is present in curricula and has a long tradition, but the important constant of bringing music at school are the extracurricular musical activities which also represents a specific European model of how music at school can be developed and improved. The model of conducting extracurricular music activities mostly works and the students opt for some of the music activities at school and acquire new knowledge and develop their musical skills. Apart from the choir, as the most frequent and mostly attended activity, the offer in schools is different and often depends on the teacher's affinities. In order to get more and more students involved in extracurricular music activities and thus spend their free time in an organized way, which is a very important social moment because they reduce the negative consequences of free time, it is extremely important to offer new activities and modernize the existing ones. The described activity of listening to music with a concert experience is one of the ways to engage students in the extracurricular process and provide them with the prospect of progress.

The society needs an individual who lives culture and art, is a part of cultural and artistic events, participates and artfully expresses, critically reviews, explores and creates, and with their work affects the prosperity of the narrower and wider community. All this is developed by participating in extracurricular music activities. Students will, as stated in the Subject Curriculum $(2019$, p. 3): "as competent cultural users actively participate in the musical life of their environment (as performers, audience or creators), contributing to the preservation, transfer, renewal and dissemination of cultural heritage." The school, thanks to extracurricular music activities, becomes an educational institution, richer and more lifelike. That is why, extracurricular activities should be and remain (or become!) an important part of not only the Croatian but also the European educational system.

Funding sources: No financial support was received for this study. 
Authors' contribution: The author emphasizes the value of the extracurricular music activities in Croatian schools regarding the acquisition of new knowledge and development of the students' musical skills. The author present the research project Schools@Concerts: Tuning up for the Music Experience which was done in Croatia and present a new possibility to approach the extracurricular activities. The new extracurricular music activity Listening to Music with Concert Experience is presented with the intention to familiarize students with (classical) music during the work in the extracurricular activity and by visiting to a concert.

Conflict of interest: The authors declare no conflict of interest.

\section{ACKNOWLEDGMENTS}

No additional acknowledgements.

\section{REFERENCES}

Bernhofer, A., Vidulin, S., \& Beqiri-Vula, L. (2020). European comparative research project Schools@Concerts: Experiences from Croatia and Macedonia (reviewed and accepted for publishing. In V. Svalina, (Ed.), Music pedagogy in the context of present and future changes 6.

Broh, B. A. (2002). Linking extracurricular programming to academic achievement: Who benefits and why? Sociology of Education, 75(1), 69-95. https://doi.org/10.2307/3090254.

Delle Fave, A., \& Bassi, M. (2000). The quality of experience in adolescents daily lives: Development perspectives. Genetic Social and General Psichology Monographs, 126(3), 347-367.

Flammer, A., \& Schaffner B. (2003). Adolescent leisure across European nations. New Direction for Children Adolescent Development, 99, 65-78. https://doi.org/10.1002/cd.67.

Gilman, R., Meyers, J. \& Perez, L. (2004). Structured extracurricular activities among adolescents: Findings and implications for school psychologists. Psychology in the Schools, 41(1), 31-41. https://doi.org/10. 1002/pits.10136.

Hrvatski nacionalni obrazovni standard. [Croatian National Educational Standard]. (2005). Vodič kroz Hrvatski nacionalni obrazovni standard za osnovnu školu. Zagreb: Ministarstvo znanosti, obrazovanja i športa.

Ilišin, V. \& Radin, F. (eds). (2002). Mladi uoči trećeg milenija [Young on the eve of the third millenium]. Zagreb: Institut za društvena istraživanja u Zagrebu i Državni zavod za zaštitu obitelji, materinstva i mladeži.

Kurikulum za nastavni predmet Glazbene kulture za osnovne škole i Glazbene umjetnosti za gimnazije u Republici Hrvatskoj (Curriculum for Music Culture in the Compulsory School and Music Art in Gymnasiums in the Republic of Croatia). (7/2019). Zagreb: Narodne novine.

Marsh, H. W. \& Kleitman, S. (2003). Extracurricular school activities: The good, the bad, and the nonlinear. Harvard Educational Review, 72(4), 464-514. https://doi.org/10.17763/haer.72.4.051388703v7v7736.

Mc Hale, S. M., Crouter, A. C., \& Tucker, C. J. (2001). Free-time activities in middle childhood: Links with adjustment in early adolescence. Child Development, 72(6), 1764-1778. https://doi.org/10.1111/14678624.00377.

Mlinarević, V. \& Brust Nemet, M. (2012). Izvannastavne aktivnosti u školskom kurikulumu [Extracurricular activities in the school curriculum]. Osijek: Sveučilište J. J. Strossmayera, Učiteljski fakultet u Osijeku. 
Nacionalni okvirni kurikulum za predškolski odgoj i obrazovanje te opće obvezno i srednjoškolsko obrazovanje [National Curriculum Framework for pre-school education and general compulsory and secondary education]. (2011). Zagreb: Ministarstvo znanosti, obrazovanja i športa.

Nastavni plan i program za osnovnu školu [Teaching plan and program for the compulsory school]. (2006). Zagreb: Ministarstvo znanosti, obrazovanja i športa.

Odluka NN 7/2019 [Official Gazzete] https://narodne-novine.nn.hr/clanci/sluzbeni/2019_01_7_151.html.

Pejić Papak, P., \& Vidulin, S. (2016). Izvannastavne aktivnosti u suvremenoj školi [Extracurricular activities in contemporary school]. Zagreb: Školska knjiga.

Predmetni kurikulum za nastavu glazbe u osnovnoj i srednjoj školi [Subject Curriculum of Music for Primary Compulsory and Secondary Education]. (2019). Zagreb: Ministarstvo znanosti i obrazovanja.

Prlić, N., \& Ilić, A. (2000). Slobodno vrijeme mladih u školi - kako ga vide mladi? [Free time of youth at school - how do young people see it?] Napredak, 141(4), 458-467.

Šimunović, Z. (2019). Kurikulumski pristup poučavanja u nastavi Glazbene kulture i Glazbene umjetnosti u projektu "Škola za život" [Curriculum approach in the organization of teaching of music in school in project "School for life"]. In V. Svalina (Ed.), Music pedagogy in the context of present and future changes 6. (reviewed and accepted for publishing).

Vidulin, S. (2016a). Reforme odgojno-obrazovnoga sustava u Hrvatskoj i odjeci na glazbenu nastavu u osnovnoj školi [Reforms of education system in Croatia and reflections on music teaching in primary school]. In F. Hadžić (Ed.), Muzika u društvu (pp. 312-325). Sarajevo: Muzikološko društvo FBiH, Muzička akademija Univerziteta u Sarajevu.

Vidulin, S. (2016b). Extracurricular musical activities in primary school from the teachers' point of view. In M. Sedláček (Ed.), Music - Education - Terra Cognita? (pp. 6-12). Brno: Masarykova univerzita. https://doi.org/10.5817/CZ.MUNI.P210-8443-2016.

Vidulin, S. (2019). Ishodi i utjecaj izvannastavnih glazbenih aktivnosti na učenika, učitelja i školu [Outcomes and influence of exstracurricular music activities on the pupil, teacher and school]. In V. Marković, \& J. Martinović-Bogojević (Eds.), Muzička pedagogija: Izazov, inspiracija i kreacija (pp. 4360). Cetinje: Muzička akademija, Cetinje.

Vidulin-Orbanić, S. (2007). Izvannastavne (glazbene) aktivnosti: mjesto suživota, kreativnosti i stvaralaštva [Extracurricular (music) activities: A place of coexistence and creativity]. Rovinj: OŠ Vladimira Nazora.

Vidulin-Orbanić, S. (2013). Glazbeno stvaralaštvo: teorijski i praktični prinos izvannastavnim glazbenim aktivnostima [Musical creativity: theoretical and practical contribution to extracurricular musical activities]. Pula: Udruga za promicanje kvalitete i poticanje izvrsnosti u odgoju i obrazovanju "SEM".

Vidulin, S., \& Martinović, V. (2015). Umjetnička glazba i oblikovanje kulturnoga identiteta učenika [Classical (art) music and shaping of pupils' identity]. Školski vjesnik, 64(4), 573-588. https://hrcak.srce.hr/153129. Vidulin, S., \& Pejić Papak, P. (2018). Vannastavne aktivnosti: Pogled u budućnost [Extracurricular activities: Look into the future]. Artefact, 4(1), 15-25. https://doi.org/10.5937/artefact4-17214.

Vidulin, S., \& Radica, D. (2017). Spoznajno-emocionalni pristup slušanju glazbe u školi: teorijsko polazište [Cognitive-emotional approach to listening to music in school: A theoretical starting point]. In S. Vidulin. (ed.), Glazbena pedagogija u svjetlu sadašnjih i budućih promjena 5 (pp. 55-71). Pula: Sveučilište Jurja Dobrile u Puli.

Open Access statement. This is an open-access article distributed under the terms of the Creative Commons AttributionNonCommercial 4.0 International License (https://creativecommons.org/licenses/by-nc/4.0/), which permits unrestricted use, distribution, and reproduction in any medium for non-commercial purposes, provided the original author and source are credited, a link to the CC License is provided, and changes - if any - are indicated. 